\title{
SEMANGAT BELAJAR MAHASISWA PADA MASA PANDEMI COVID-19
}

\author{
ST IBRAH MUSTAFA KAMAL1, ABDUL RAHMAN², MARIYAL QIBTIYAH ${ }^{3}$ \\ Universitas Islam Negeri Alauddin Makassar ${ }^{1}$, Kementerian Agama Kabupaten \\ Pinrang ${ }^{2}$, Universitas Negeri Makassar ${ }^{3}$ \\ Email: st.ibramk@uin-alauddin.ac.id ${ }^{1}$, muhqaddafirahman@gmail.com², \\ mariyalmustafa@yahoo.com ${ }^{3}$
}

(Article History)

Received March 18, 2021; Revised June 13, 2021; Accepted June 17, 2021

\begin{abstract}
The Spirit of Student Learning During The Covid-19 Pandemic
This study aims to explain in detail how the objective conditions of student enthusiasm for learning are during the Covid-19 pandemic. The research was conducted at UIN Alauddin Makassar with a sample of 79 students. The data collection technique in this study uses a survey using a google form in order to reach students and uses a Likert scale in filling out the survey. The data analysis technique used in this study is to calculate the percentage of data from each indicator, then interpret the data presentation scores and analyze each indicator in depth. The results of this study indicate that the enthusiasm for learning of UIN Alauddin Makassar students is "very good", this is obtained from a survey of 87.5 percent. The results of this study can be used as one of the evaluation materials and the development of students in the Government and Educational Institutions in general and universities in particular which of course carry out online learning in the Covid-19 pandemic era.
\end{abstract}

Keywords: Spirit of Learning, Online Learning, Pandemi Covid-19

\section{Abstrak: Semangat Belajar Mahasiswa Pada Masa Pandemi Covid-19}

Penelitian ini bertujuan untuk menjelaskan secara rinci bagaimana kondisi objektif semangat belajar mahasiswa di masa pandemi Covid-19. Penelitian dilakukan di UIN Alauddin Makassar dengan sampel penelitian adalah 79 mahasiswa. Teknik pengumpulan data dalam penelitian ini menggunakan Survei dengan menggunakan google form agar dapat menjangkau mahasiswa dan menggunakan skala Likert dalam pengisian survei. Teknik analisis data yang digunakan dalam penelitian ini adalah menghitung persentase data dari setiap indikator, kemudian menginterpretasikan skor penyajian data dan menganalisis setiap indikator secara mendalam. Hasil penelitian ini menunjukkan bahwa semangat belajar mahasiswa UIN Alauddin Makassar "sangat baik", hal ini diperoleh dari Survei sebesar 87,5 persen. Hasil penelitian ini bisa digunakan menjadi salah satu materi evaluasi maupun pengembangan peserta didik di pemerintah dan Lembaga Pendidikan pada umumnya serta perguruan tinggi pada khususnya yang tentunya melaksanakan pembelajaran online pada era pandemic Covid-19.

Kata Kunci: Semangat Belajar, Pembelajaran Daring, Pandemi Covid-19 


\section{PENDAHULUAN}

ada tahun 2011 di Jerman menjadi awal munculnya Revolusi Industri 4.0 sebagai langkah awal bagi kemajuan konsep kebijakan ekonomi (Mosconi, 2015) rencana pada revolusi industri dengan memakai teknologi informasi tingkat tinggi (Yin dan Qin, 2019). Pada masa Revolusi Industri 4.0 membuat batasan yaitu antar manusia terhadap komunikasi, mesin industri dan teknologi informasi yang memberi dampak terhadap masyarakat (Kehdinga dan Fomunyam, 2019). Perubahan baru dimasyarakat terjadi setelah perkembangan teknologi di masa revolusi industry 4.0. Masing-masing individu diharuskan mengikuti kemajuan teknologi serta dapat memanfaatkannya sehingga memudahkan bagi masyarakat (Sarıçoban et al., 2019).

Pada dunia Pendidikan penggunaan teknologi termasuk topik yang sangat penting dan sering didiskusikan disetiap pertemuan (Orgaz et al., 2018). Dengan adanya teknologi, tenaga pendidik bisa memanfaatkannya untuk penyediaan ruang bagi proses pembelajaran daring (Husaini, 2014), pembelajaran tidak mempunyai batas tertentu baik di ruang kelas maupun di luar kelas (Denker, 2013), pembelajaran jarak jauh dapat dilakukan sehingga mendorong inovasi baru dalam membuat sistem pengajaran atau di luar kampus. (Almeida dan Simoes, 2019).

Menurut Mustofa (2019), “pembelajaran daring menggunakan metode pembelajaran yang baru, dilakukan secara virtual oleh para pengajar dan mahasiswa dalam melakukan aktivitas berlajar secara terpisah. Pembelajaran daring dapat dilakukan dengan menggunakan akses jejaring internet dan web 2.0 yaitu teknologi yang membantu dalam pelaksanaan pembelajaran daring". Telah sering dilakukan pembelajaran daring pada berbagai perguruan tinggi, berdasarkan beberapa penelitian (Crews dan Parker, 2017), pembelajaran daring ini memberikan fasilitas berupa akses belajar bagi semua orang, maka akan lebih memudahkan seseorang untuk belajar dalam ruang lingkup kelas (Ahmed, 2018), pembelajaran daring ini memberikan fasilitas berupa akses belajar bagi semua orang, maka akan lebih memudahkan seseorang untuk belajar dalam ruang lingkup kelas (Ahmed, 2018), Selain itu, pembelajaran daring diartikan sebagai metode yang tepat untuk digunakan oleh kampus. Namun, menurut Pilkington (2018) "pembelajaran online tidak bisa dilakukan pada seluruh proses perkuliahan".

Corona Virus Diseases 2019 (Covid-19) merupakan jenis virus terbaru, ditemukan pada manusia dengan tingkat penyebaran yang sangat cepat. menurut WHO akan banyak virus yang bermunculan yang menjadi masalah serius bagi Kesehatan global (Zhou et al., 2020). Menurut Sahu (2020), “Pandemi Covid-19 merupakan masalah global, salah satunya berdampak pada aspek dunia pendidikan yaitu turunnya minat dan hasil kerja pada mahasiswa". Pada era ini proses pembelajaran luring harus digantikan dengan pembelajaran daring sehingga proses pembelajaran berjalan lebih efektif (Sintema, 2020), maka pola pembelajaran guru/dosen harus berubah dan mengharuskan untuk 
mempersiapkan bahan materi dan kesiapan dalam mengajar secara virtual menggunakan media teknologi (Clark 2020).

Pembelajaran daring memiliki kelebihan yang memungkinkan mahasiswa untuk melakukan pembelajaran secara fleksibel, kapanpun dan dimanapun. Selain itu, mahasiswa bisa berkomunikasi secara virtual dengan beberapa aplikasi media sosial misalkan telepon atau live chat, zoom, google classroom, dan lainnya. Nakayama, Mutsuura, and Yamamoto (2014) menyatakan bahwa semua literatur menyimpulkan bahwa tidak semua mahasiswa dapat menerima dengan baik pembelajaran online ini, bisa disebabkan perbedaan atmosfir dan lingkungan belajar yang berbeda-beda dan karakteristik peserta didik. Semua tergantung semangat yang dimiliki mahasiswa dan itu merupakan salah satu keberhasilan dalam pembelajaran.

Motivasi yang diartikan sebagai semangat untuk mencapai tujuan tertentu. Dalam pembahasan ini yang dimaksudkan adalah motivasi dalam belajar. Menurut Brophy, 2004 motivasi merupakan konsep teoritis yang menjelaskan arah, ketekunan dan kualitas perilaku demi mencapai tujuan tertentu. Motivasi menggambarkan keinginan yang kuat untuk melakukan sesuatu dengan tujuan tertentu baik fisik atau mental (Lee dan Martin, 2017). Motivasi sangat berpengaruh tentang pengetahuan kita, kapan memilih untuk belajar dan bagaimana kita belajar (Ryan, 2012). Dengan termotivasi salah satu dampaknya maka akan menimbulkan semangat belajar.

Dari berbagai hasil penelitian mengemukakan bahwa mahasiswa yang memiliki keingingin belajar akan lebih menikmati proses belajar dan akan memperlihatkan hasil belajar, kreativitas dan ketekunan yang baik (El-Seoud et al., 2014). Faktanya, semangat belajar menjadi hal penting dalam mencapai keberhasilan belajar pada masa pandemi dengan metode belajar daring, oleh sebab itu peneliti tertarik dalam menganalisis tentang bagaimana semangat mahasiswa pada proses pembelajaran daring pada era pandemi Covid-19. Tujuan penelitian ini tentunya memperlihatkan tingkat semangat belajar mahasiswa pada masa pandemic Covid-19.

Semangat merupakan keinginginan berupa perasaan dan tindakan. Semangat ialah kondisi saat ingin mengerjakan satu atau lebih tindakan. Maka, semangat berguna untuk memotivasi dalam bertindak (Novian, 2020). Motivasi yang diartikan sebagai semangat untuk mencapai tujuan tertentu, pada artikel ini dimaksudkan ialah motivasi belajar.

Di masa pandemi ini motivasi belajar sangat berkaitan dengan pencapaian prestasi belajar, yang merupakan salah satu faktor bagi mahasiswa untuk lebih berkonsentrasi dan memberikan keinginan yang lebih agar dapat lebih bersemangat dalam menjalani proses belajar mengajar. Meningkatnya motivasi mahasiswa dalam belajar, maka mahasiswa semakin giat dan tekun untuk meningkatkan prestasi, sedangkan mahasiswa yang mempunyai motivasi belajar 
rendah maka akan terlihat acuh tak acuh juga mudah putus asa yang akan menghasilkan prestasi yang semakin menurun di masa pandemi ini.

Belajar merupakan proses adaptasi perilaku dalam satu kondisi, bahkan di masa pandemi yang terasa hampa. Keadaan belajar saat ini dilakukan dengan virtual. Motivasi yang rendah terkadang menghasilkan proses belajar yang tidak maksimal (B. Muhaemin, 2013). Belajar adalah proses berubahnya perilaku sebagai hasil dari perubahan lingkungan. Pada proses pembelajaran ini mahasiswa secara bertahap akan merasakan perubahan baik dalam lingkungan, proses belajar, perkembangan keterampilan, dan ilmu yang diperoleh.

Motivasi merupakan faktor pendukung semangat belajar mahasiswa yang paling berpengaruh mengingat sekarang adalah masa pandemi Covid-19. Ada beberapa peserta didik yang mempunyai motivasi belajar yang baik pada masa pandemi Covid-19, ada pula yang menurun motivasi belajarnya, maka perlu diambil beberapa solusi dalam mengatasi masalah tersebut untuk meningkatkan kembali motivasi belajar.

Berkaitan dengan motivasi, menurut teori Abraham Maslow tentang motivasi dan hirarkinya dapat dijadikan acuan. Dalam pemikiran Maslow, kebutuhan yang paling penting dan susah ialah kebutuhan aktualisasi diri. Aktualisasi diri terhadap motivasi bertujuan dalam meningkatkan potensi diri dengan maksimal (Maslow, 1943). Menurut jenisnya, motivasi terbagi menjadi motivasi intrinsik dan ekstrinsik. Motivasi intrinsik adalah motivasi internal untuk melakukan sesuatu demi mencapai tujuan tertentu, sebagai contoh: ada mahasiswa yang menyukai mata kuliah tertentu akan belajat lebih giat untuk menghadapi ujian. Sedangkan, motivasi ekstrinsik adalah motivasi yang bersumber dari orang lain sehingga akan bertindak untuk mencapai tujuan tertentu. Motivasi ekstrinsik lebih mudah terpengaruh oleh insentif eksternal misalnya dengan adanya keuntungan atau hukuman.

Semangat belajar dipengaruhi oleh faktor intern, yang merupakan faktor yang ada dalam diri seseorang, dan faktor ekstern, merupakan factor yang ada diluar individu. Artikel ini memfokuskan diri terhadap faktor intern dan ekstern yang dapat mempengaruhi semangat belajar mahasiswa (Febianti and Joharudin, 2018).

Semangat belajar adalah salah satu faktor untuk mencapai prestasi dalam pendidikan. Semangat belajar ialah unsur penting pada proses belajar, karena dengan belajar disertai dengan semangat akan lebih memotivasi mahasiswa agar lebih semangat dalam menjalani proses belajar (Supriyono, 2018). Sangat disayangkan seseorang yang tidak memiliki semangat belajar karena tanpa semangat belajar kita akan ketinggalan tentang pengetahuan-pengetahuan yang seharusnya seorang mahasiswa sudah ketahui, tetapi karena keterlambatan dalam menelaah ilmu atau bisa dikatakan tidak memiliki minat dalam belajar jadilah tidak mengetahui apa-apa. Di masa pandemi Covid-19 ini semangat belajar lebih dibutuhkan sebab sulitnya berhadapan langsung dengan dosen saat pembelajaran 
berlangsung. Maka seorang mahasiswa dituntut untuk lebih menguasai pembelajaran tanpa bergantung pada dosen, bahkan di masa pandemi ini belajar secara otodidak sangat perlu dan itu membutuhkan semangat belajar.

\section{METODE PENELITIAN}

Penelitian ini merupakan penelitian kuantitatif (Nenty, 2009). Penelitian kuantitatif adalah penelitian yang dilakukan dalam membuktikan kebenaran dengan teknik analisis data menggunakan teknik kuantitatif (statistika) secara objektif (Creswell, 2007). Pinsonneault and Kraemer (1993) mengatakan "Metode survei merupakan metode penelitian yang bertujuan untuk menggambarkan secara kuantitatif aspek-aspek spesifik dari populasi tertentu sehingga pengumpulan datanya dilakukan kepada sekolompok orang yang hasilnya dapat digeneralisasi kembali ke dalam suatu populasi tertentu". Metode survei sangat cocok digunakan pada penelitian ini, sehingga dapat melihat bagaimana motivasi mahasiswa dalam analisis semangat belajar mahasiswa pada era pandemi Covid-19. Subjek dalam penelitian ini adalah mahasiswa UIN Alauddin Makassar berjumlah 79 orang yang mendapatkan pembelajaran daring selama masa pandemi Covid-19. Instrumen yang digunakan dalam penelitian ini menggunakan data survei.

Pada penelitian ini metode survei dalam bentuk kuisioner pada aplikasi google form agar mudah diakses oleh sampel/mahasiswa. Kuesioner yang dibuat bertujuan untuk membuktikan secara detail tentang semangat belajar mahasiswa dalam pembelajaran daring selama era pandemi Covid-19, adapun jenis surveinya menggunakan Skala Likert yang digunakan sebagai parameter untuk mengukur sikap, pendapat, dan persepsi individu atau sekolompok orang terhadap fenomena social (Sugiyono, 2016). Adapun tabel Skala Likert disajikan di bawah ini.

Tabel 1. Skala Likert

\begin{tabular}{c|c}
\hline Kriteria Penilaian & Skala Penilaian \\
\hline Sangat Setuju & 5 \\
Setuju & 4 \\
Cukup/Netral & 3 \\
Tidak Setuju & 2 \\
Sangat Tidak Setuju & 1
\end{tabular}

Sumber: Sugiyono (2016)

Selain itu, Analisa data yang digunakan untuk menghitung persentase hasil skor yang didapatkan, yaitu dengan rumus sebagai berikut:

\section{Tabel 2. Rumus Skor Presentase Responden}

Rumus Index \% =[T x Pn] : V x 100

Sumber: Sugiyono (2016)

Keterangan: T: Total jumlah responden yang memilih; Pn: Pilihan angka skor Likert; Y: Skor Ideal 
Hasil presentase yang telah diperoleh dilakukan interpretasi skor berdasarkan tabel interval berikut ini.

Tabel 3. Kriteria Interpretasi Skor

\begin{tabular}{c|c}
\hline Presentase & Keterangan \\
\hline $0 \%-19,99 \%$ & Sangat kurang baik \\
$20 \%-39,99 \%$ & Kurang baik \\
$40 \%-59,99 \%$ & Cukup \\
$60 \%-79,99 \%$ & Baik \\
$80 \%-100 \%$ & Sangat baik \\
\hline
\end{tabular}

Sumber: Olah data peneliti, 2021

Persentase kriteria pada Tabel 3 menjadi acuan untuk menganalisis secara detail dan menyimpulkan bagaimana semangat belajar mahasiswa UIN Alauddin Makassar pada pembelajaran daring selama era pandemi Covid-19.

\section{HASIL PENELITIAN DAN PEMBAHASAN}

Survei semangat belajar pada era pandemi Covid-19 diberikan kepada 79 mahasiswa UIN Alauddin Makassar. Hasil dari survei menunjukkan bahwa semangat belajar yang tinggi pada mahasiswa yang ingin mendapatkan skor yang tinggi, dalam mencapai tujuan tersebut dengan rajin belajar walau terkadang harus otodidak dikarenakan pandemi Covid-19. Aspek yang diperhatikan dalam melihat kedisiplinan mahasiswa dalam perkuliahan online diantaranya adalah (1) Mengikuti seluruh kegiatan perkuliahan online dengan angkapersentase $71,8 \%$ termasuk kriteria yang baik, hasil ini menjadi patokan dalam proses pembelajaran, angka presentase ini memperlihatkan bahwa mahasiswa cukup baik dalam mengikuti seluruh kegiatan perkuliahan online; (2) Mengerjakan tugas perkuliahan online dengan skor 97,5\% kriteria yang sangat baik, yaitu mahasiswa menerima materi yang diberikan dengan sangat baik sehingga sangat muda untuk mengerjakan tugas, sedangkan pada masa pandemi Covid-19 tugas yang diberikan jauh lebih banyak dibandingkan dengan sebelumnya; (3) On time mengikuti perkuliahan online angka persentase $88,6 \%$ termasuk kriteria sangat baik sehingga ketegasan dosen dalam mengabsen sangat berguna untuk tetap disiplin meski hanya kuliah daring; 4) Dapat mengerjakan quiz/ujian perkuliahan online dengan angka persentase $97,5 \%$ termasuk kriteria baik, yang artinya bahwa pembelajaran secara online tidak selalu berjalan dengan lancar; 5) Tidak adanya hambatan selama mengikuti perkuliahan online dengan angka persentase $82,1 \%$ yaitu kriteria yang sangat baik, yang berarti bahwa perkuliahan daring ini hampir tidak memiliki hambatan, hanya 17,9\% yang kurang paham dengan perkuliahan online ini.

Dari kelima aspek di atas, para pengajar dan mahasiswa pada proses belajar memiliki hubungan timbal balik, seperti dalam meningkatkan minat dan semangat belajar mahasiswa, diantaranya adalah penggunaan media dan bahan ajar yang interaktif, dan pemakaian aplikasi yang menunjang pembelajaran yang digunakan 
oleh dosen atau para pengajar. Selain itu, faktor yang menyebabkan menurunnya kualitas belajar mahasiswa untuk mengikuti dan memahami materi disebabkan oleh akses jaringan yang buruk (Husamah, 2014). Mengutip dalam penelitian Husamah, "Apabila akses jaringan buruk, maka menyebabkan proses belajar menjadi terhambat, yang menyebabkan pembelajaran menjadi tidak efektif". Pada penelitian Flora Siagian (2015) dikatakan bahwa "Semangat para pengajar/guru/dosen dalam proses mengajar sangat berkaitan terhadap keinginan peserta didik dalam, sehingga terjadi peningkatan minat dan keinginan mahasiswa dalam mencapai skor tertinggi sebagai hasil proses pembelajaran". Motivasi dalam meningkatkan skor tertinggi dapat didukung dengan berusaha dan tekun selama proses pembelajaran berlangsung. Berikut hasil Survei semangat belajar mahasiswa dalam bentuk tabel:

\section{Tabel 4.Hasil Survei Semangat Belajar Mahasiswa}

\begin{tabular}{l|c|c}
\hline \multicolumn{1}{c|}{ Aspek } & Presentase & Kriteria \\
\hline Mengikuti Seluruh Kegiatan Perkuliahan Online & $71,8 \%$ & Baik \\
Mengerjakan Tugas Perkuliahan Online & $97,5 \%$ & Sangat Baik \\
On Time Mengikuti Perkuliahan Online & $88,6 \%$ & Sangat Baik \\
Dapat Mengerjakan Quiz/Ujian Perkuliahan Online & $97,5 \%$ & Sangat Baik \\
Tidak Adanya Hambatan Selama Mengikuti & $82,1 \%$ & Sangat Baik \\
Perkuliahan Online & & \\
\hline Rata-Rata & $87,5 \%$ & Sangat Baik \\
\hline
\end{tabular}

Sumber: Olah data peneliti, 2021

Berdasarkan Tabel 4. hasil survei semangat belajar mahasiswa terhadap pembelajaran daring selama era pandemi Covid-19 yang diperoleh memperlihatkan skor presentase rata-rata secara keseluruhan yaitu 87,5\% dengan kategori sangat baik, sehingga dapat diartikan bahwa mahasiswa UIN Alauddin Makassar memiliki semangat belajar yang sangat tinggi terhadap pembelajaran daring selama masa pandemi Covid-19. Menurut Teting, Lehyun, and Angariani (2020) mengutip bahwa pembelajaran tatap muka di kelas dapat diganti dengan pembelajaran online. Permasalahan yang sering terjadi adalah mata kuliah yang memiliki karakternya masing-masing belum tentu cocok dengan pembelajaran online ini. Seluruh materi perkuliahan disampaikan dengan metode ceramah yang lebih efektif pada proses pembelajaran daring jika dibandingkan dengan materi dengan metode demonstrasi atau metode yang melibatkan mahasiswa secara fisik.

Permasalahan lain yang kemungkinan terjadi adalah gangguan jaringan dan teknis lainnya. Maka dari itu Menteri Pendidikan dan Kebudayaan (Mendikbud) memberikan keluwesan kepada satuan pendidikan untuk membuat pedoman pelaksanaan Bekerja Dari Rumah (BDR) dan pembelajaran daring disesuaikan dengan kebutuhan setempat.

Perkuliahan luring atau tatap muka menghasilkan pembelajaran yang lebih efektif. Prestasi akademik yang sama, namun diperoleh dalam proses 
pembelajaran yang berbeda yaitu pembelajaran daring, maka harus mendapat perhatian yang lebih sehingga dapat mencapai hasil dan prestasi yang sama saat pembelajaran luring. Perubahan metode pembelajaran di era pandemi ini menjadikan pembelajaran during sebagai metode yang tepat, oleh karena itu secara perlahan dosen harus dapat beradaptasi dengan adanya perubahan dan juga perlu memperhatikan berbagai aspek seperti infrastruktur, tahapan dan aturannya. Direktur Jenderal Perguruan Tinggi mengatakan bahwa pelaksanaan pembelajaran daring tidak perlu kurikulum darurat, maka perguruan tinggi dan tenaga pendidik dapat menggunakan teknologi secara efektif dan efisien dalam pelaksanaan pembelajaran daring (World Health Organization, 2020).

Menurut penulis, era pandemi Covid-19 tidak menghalangi semangat belajar mahasiswa UIN Alauddin Makassar dalam melakukan pembelajaran secara daring. Di tengah kedaruratan yang melanda dunia tidak ada pilihan lain selain menerapkan konsep pembelajaran secara daring. Mengutip Hung et al. (2010) yang mengatakan sebagai berikut:

"Ada beberapa catatan yang harus diperhatikan oleh pengajar agar pembelajaran daring tetap optimal yaitu berkaitan dengan kesiapan belajar diantaranya adalah kepercayaan diri terhadap penggunaan komputer/internet, pembelajaran secara mandiri, pengendalian pelajar/mahasiswa, motivasi untuk belajar, dan kepercayaan diri terhadap komunikasi secara online".

\section{Solusi Untuk Mahasiswa yang Tidak Memiliki Semangat Belajar}

Salah satu faktor penyebab mahasiswa tidak memiiki semangat belajar pada masa pandemi ini adalah mahasiswa kurang aktif bertanya dan mengungkapkan pendapatnya saat berinteraksi secara virtual maupun di kelas, mahasiswa akan lebih percaya diri bertanya dan bisa mengemukakan pendapat hanya kepada teman dekatnya. Penyebab dari problematika tersebut adalah (1) Mahasiswa mengalami kesalahan konsep, dan prinsip; (2) Aktivitas pembelajaran belum optimal; (3) Minat belajar mahasiswa rendah; (4) Interaksi antar mahasiswa kurang optimal. Masalah-masalah tersebut bermuara pada rendahnya hasil belajar mahasiswa (Amir and Kurniawan, 2016).

Membangkitkan semangat belajar tidaklah mudah, mengingat sekarang masa pandemic maka seorang mahasiswa bisa melakukan berbagai usaha untuk meningkatkan motivasi belajar. Berikut cara membangkitkan semangat belajar diri sebagai pelajar/ mahasiswa menurut (Rusdiansyah, 2019) diantaranya adalah :

1. Gunakan metode dan kegiatan yang beragam. Melakukan hal yang sama secara terus-menerus dapat menimbulkan kebosanan dan menurunkan semangat belajar;

2. Pada usia muda sebaiknya diisi dengan melakukan kegiatan berkreasi, menulis, berpetualang dan menciptakan sesuatu;

3. Jangan menjadi mahasiswa yang pasif karena ini dapat menurunkan minat dan mengurangi rasa kaingintahuan; 
4. Gunakan metode belajar yang aktif dengan bercengkrama atau berdiskusi bersama kawan;

5. Rutinlah berkumpul dan bertukar pikiran.

Dengan mempraktikkan iLearning Education mahasiswa bisa tetap terdorong dan memiliki semangat belajar dalam proses pembelajaran iLearning, sehingga mahasiswa dapat mengerjakan tugas tepat waktu dan lebih antusias dalam menerima materi yang diberikan oleh dosen (Handayani, Kusumahati, and Badriah, 2017).

Pada pembelajaran, seorang pendidik tidak dapat memberikan motivasi secara maksimal apabila mereka dalam keadaan belum makan atau dalam keadaan stres. Keadaan ini menghambat motivasi bejar pada mahasiswa. Konstruksi hirarki kebutuhan menurut Maslow ini menjadi bahan perdebatan di kalangan pakar psikologi, khususnya pakar psikologi pendidikan. Jika kebutuhan seseorang dalam hal ini adalah dosen bersifat hirarkis, maka ada yang berpendapat tidak demikian. Pada sebagian dosen kebutuhan kognitif lebih penting daripada kebutuhan harga diri. Rendahnya semangat belajar mahasiswa sebagaimana yang banyak terjadi, maka solusinya harus komprehensif, integratif, dan simultan. Pemecahan masalah yang diberiikan dapat memberikan suasana dan lingkungan yang lebih bersahabat dan lebih memotivasi. (Wahab , 2008).

Soewadji (1994) mengatakan:

"Yang dapat dilakukan untuk meningkatkan semangat belajar ialah merencanakan pembelajaran dengan atmosfer yang bersahabat. Pembelajaran disebut bersahabat atau menyenangkan jika dalam proses tersebut terasa suasana yang menarik, tanpa beban, rileks, dan kreatif, dan dengan adanya keterlibatan penuh dosen dan mahasiswa, maka proses pembelajaran terasa bersemangat, gembira, dan memberikan konsentrasi tinggi".

Sedangkan, pembelajaran menjadi tidak menyenangkan jika atmosfer yang dirasakan mengekang, menakutkan, merasa tidak penting, malas, bosan, dan merasa topik yang diberikan tidak menarik (Nainggolan, 2020).

Penulis berpendapat bahwa semangat belajar mahasiswa UIN Alauddin Makassar di masa pandemi covid-19 ini tergolong sangat baik, karena $80 \%$ lebih mahasiswa UIN Alauddin Makassar tidak menjadikan pembelajaran daring sebagai alasan untuk bermalas-malasan, tidak sedikit orang berfikir bahwa karena hanya perkuliahan online maka dapat bersantai di rumah. Penelitian ini dapat dijadikan motivasi untuk diri sendiri agar tidak bermalas-malasan, mengingat bahwa semangat belajar itu sangat penting bukan hanya di masa pandemi ini tapi akan diperlukan sepanjang masa.

\section{PENUTUP/SIMPULAN}

Penelitian ini menyimpulkan bahwa terdapat 5 aspek motivasi belajar dengan angka rata-rata presentase $87,5 \%$ dengan kriteria yang sangat baik. Berdasarkan 
hasil tersebut pada era pandemi Covid-19 tidak menghalangi semangat belajar mahasiswa yang tinggi, walaupun dengan lingkungan belajar baru yang mengaharuskan mahasiswa untuk dapat beradaptasi. Dalam kondisi darurat seperti ini, maka mahasiswa dan dosen berinteraksi pada proses pembelajaran dilakukan secara daring atau online dengan memanfaatkan secara maksimal teknologi yang ada.

Penelitian ini diharapkan bermanfaat bagi semua pihak yang menyelenggarakan proses pembelajaran secara daring atau online dan juga menjadi bahan diskusi untuk meningkatkan motivasi belajar mahasiswa dalam perubahan di era pandemi. Selain itu, juga para pendidik dan mahasiswa dapat mempersiapakan semua sarana seperti media, bahan materi, penggunaan aplikasi dan akses jaringan.

\section{DAFTAR PUSTAKA}

Ahmed, R. (2018). Effects of Online Education on Encoding and Decoding Process of Students and Teachers. MCCSIS 2018 - Multi Conference on Computer Science and Information Systems; Proceedings of the International Conferences on e-Learning 2018, 2018-July, 42-48.

Almeida, F., \& Simoes, J. (2019). The Role of Serious Games, Gamification and Industry 4.0 Tools in The Education 4.0 Paradigm. Contemporary Educational Technology, 10(2), 120-136. https://doi.org/10.30935/cet.554469

Amir, M. F., \& Kurniawan, M. I. (2016). Penerapan Pengajaran Terbalik untuk Meningkatkan Hasil Belajar Mahasiswa PGSD UMSIDA pada Materi Pertidaksamaan Linier. PEDAGOGIA: Jurnal Pendidikan, 5(1), 13. https://doi.org/10.21070/pedagogia.v5i1.85

B, M. (2013). Urgensi Motivasi Dalam Meningkatkan Semangat Belajar Siswa. Adabiyah. 13(1), 47-54.

Brophy, J. (2004). Students to Second Edition Moti vating Learn. Routledge. 7-25.

Clark, H., Coll-Seck, A. M., Banerjee, A., Peterson, S., Dalglish, S. L., Ameratunga, S., Balabanova, D., Bhutta, Z. A., Borrazzo, J., Claeson, M., Doherty, T., El-Jardali, F., George, A. S., Gichaga, A., Gram, L., Hipgrave, D. B., Kwamie, A., Meng, Q., Mercer, R., ... Costello, A. (2020). After COVID-19, a future for the world's children? The Lancet, 396(10247), 298-300. https://doi.org/10.1016/S0140-6736(20)31481-1

Creswell, J. W. (2007). Research Design: Qualitative, Quantitative and Mixed Method Aproaches. SAGE Publications. https://doi.org/10.4135/9781849208956

Crews, J., \& Parker, J. (2017). The Cambodian experience: exploring university students' perspectives for online learning. Issues in Educational Research, 27(4), 697-719.

Denker, K. J. (2013). Student Response Systems and Facilitating the Large Lecture Basic Communication Course: Assessing Engagement and Learning. In Communication Teacher, 27(1), 50-69. https://doi.org/10.1080/17404622.2012.730622 
Febianti, Y. N., \& Joharudin, M. (2018). Faktor-Faktor Ekstern yang Mempengaruhi Prestasi Belajar Mahasiswa. Edunomic Jurnal Pendidikan Ekonomi, 5(2), 76. https://doi.org/10.33603/ejpe.v5i2.246

Flora Siagian, R. E. (2015). Pengaruh Minat dan Kebiasaan Belajar Siswa terhadap Prestasi Belajar Matematika. Formatif: Jurnal IImiah Pendidikan MIPA, 2(2), 122-131. https://doi.org/10.30998/formatif.v2i2.93

Handayani, I., Kusumahati, H., \& Badriah, A. N. (2017). Pemanfaatan Google Spreadsheet Sebagai Media Pembuatan Dashboard pada Official Site iFacility $\begin{array}{llll}\text { di Perguruan } & \text { Tinggi. } & \text { Sisfotenika, } & 777 .\end{array}$ https://doi.org/10.30700/jst.v7i2.155

Hung, M. L., Chou, C., Chen, C. H., \& Own, Z. Y. (2010). Learner Readiness for Online Learning: Scale Development and Student Perceptions. Computers and Education, 55(3), 1080-1090. https://doi.org/10.1016/j.compedu.2010.05.004

Husaini, M. (2014). Pemanfaatan Teknologi Informasi dalam Bidang Pendidikan (Eeducation). Jurnal Mikrotik, 2(1), 1-5. https://doi.org/10.31219/osf.io/ycfa2

Husamah. (2014). Pembelajaran Bauran (Blended Learning). In Publikasi Dosen Pendidikan Biologi UMM.

Kehdinga, D., \& Fomunyam, G. (2019). Education and the Fourth Industrial Revolution: Challenges and Possibilities for Engineering Education. IJMET_10_08_022 International Journal of Mechanical Engineering and Technology, 10(8), 271-284.

Lee, J., \& Martin, L. (2017). International Review of Research in Open and Distributed Learning August - 2017 Investigating Students 'Perceptions of Motivating Factors of Online Class Discussions. 18(5).

Maslow, A. H. (1943). Maslow's Hierarchy of Needs - Research History. In Originally Published in Psychological Review (pp. 370-396).

Mosconi, F. (2015). The New European Industrial Policy: Global competitiveness and the Manufacturing Renaissance. In The New European Industrial Policy: Global Competitiveness and the Manufacturing Renaissance (pp. 1-230). https://doi.org/10.4324/9781315761756

Mustofa, M. I., Chodzirin, M., Sayekti, L., \& Fauzan, R. (2019). Formulasi Model Perkuliahan Daring Sebagai Upaya Menekan Disparitas Kualitas Perguruan Tinggi. Walisongo Journal of Information Technology, 1(2), 151. https://doi.org/10.21580/wjit.2019.1.2.4067

Nainggolan, R. R. (2020). Pengaruh Kompetensi Guru dalam Proses Kelas Xi Bisnis Daring Dan Pemasaran Di Smk Negeri 6 Medan Tahun Ajaran 2019 / 2020. UNIVERSITAS HKBP NOMMENSEN.

Nakayama, M., Mutsuura, K., \& Yamamoto, H. (2014). Impact of learner's characteristics and learning behaviour on learning performance during a fully online course. Electronic Journal of E-Learning, 12(4), 394-408.

Nenty, H. J. (2009). Writing a Quantitative Research Thesis. International Journal of Educational Sciences. https://doi.org/10.1080/09751122.2009.11889972

Novian, S. (2020). Jurnal Artikel Teori Semangat. Jurnal Pendidikan Kewarganegaraan, 1(1), 1-41. 
Orgaz, F., Moral, S., \& Domínguez, C. (2018). Student's Attitude and Perception with the Use of Technology in the University. Journal of Educational Psychology Propositos y Representaciones, 6(2), 277-299.

Pilkington, O. A. (2018). Active Learning for an Online Composition Classroom: Blogging As an Enhancement of Online Curriculum. In Journal of Educational Technology Systems, 47(2), 213-226. https://doi.org/10.1177/0047239518788278

Pinsonneault, A., \& Kraemer, K. (1993). Survey Research in Management Information Systems: an Assessement. Journal of Management Information System.

Rusdiansyah, M. (2019). Motivasi Belajar yang Terkandung dalam Al- Qur'an Surah al -Mujadalah Ayat 11. In Skripsi Universitas Negeri Syarif Hidayatullah Jakarta.

Ryan, R. M. (2012). The Oxford Handbook of Human Motivation. In The Oxford Handbook of Human Motivation (pp. 1-598). https://doi.org/10.1093/oxfordhb/9780195399820.001.0001

Sahu, P. (2020). Closure of Universities Due to Coronavirus Disease 2019 (COVID19): Impact on Education and Mental Health of Students and Academic Staff. In Cureus. https://doi.org/10.7759/cureus.7541

Samir Abou El-Seoud, M., Taj-Eddin, I. A. T. F., Seddiek, N., El-Khouly, M. M., \& Nosseir, A. (2014). E-learning and Students' Motivation: A Research Study on the Effect of e-Learning on Higher Education. International Journal of Emerging Technologies in Learning, 9(4), 20-26. https://doi.org/10.3991/ijet.v9i4.3465

Sarıçoban, A., Tosuncuoğlu, I., \& Kırmizi, Ö. (2019). A Technological Pedagogical Content Knowledge (TPACK) Assessment of Preservice EFL Teachers Learning to Teach English as a Foreign Language. In Journal of Language and Linguistic Studies 15(3), 1122-1138. https://doi.org/10.17263/jlls.631552

Sintema, E. J. (2020). Effect of COVID-19 on the Performance of Grade 12 Students: Implications for STEM Education. Eurasia Journal of Mathematics, Science and Technology Education, 16(7), 1-6. https://doi.org/10.29333/EJMSTE/7893

Soewadji. (1994). Standardisasi Kompetensi Kepala Sekolah: Pendekatan Teori untuk Praktik, Jakarta: Kencana.

Supriyono, S. (2018). Pentingnya Media Pembelajaran Untuk Meningkatkan Minat Belajar Siswa Sd. Edustream: Jurnal Pendidikan Dasar.

Teting, B., Lehyun, Y., \& Angariani, A. (2020). Komparasi Hasil Belajar Mata Kuliah Patofisiologi Antara Pembelajaran Dalam Jaringan ( Daring ) Dengan Pembelajaran Luar Jaringan ( Luring ) Mahasiswa Semester li Stikes Dirgahayu Tahun Akademik 2019 / 2020. 2, 23-31.

Wahab, L. A. (2008). Motivasi Belajar Bahasa Arab Mahasiswa Stain Kendari (Analisis Problem dan Solusinya). Journal of Chemical Information and Modeling, 53(9), 287.

World Health Organization. (2020). Improving Early Childhood Development: WHO Guideline. $\quad$ https://www.urban.org/research/publication/improving-earlychildhood-development-policies-and-practices

Yin, Y., \& Qin, S. F. (2019). A Smart Performance Measurement Approach For Collaborative Design in Industry 4.0. Advances in Mechanical Engineering, 
11(1), 1-15. https://doi.org/10.1177/1687814018822570

Zhou, G., Chen, S., \& Chen, Z. (2020). Back to the Spring Of 2020: Facts and Hope of Covid-19 Outbreak. Frontiers of Medicine, 14(2), 113-116. https://doi.org/10.1007/s11684-020-0758-9 